\title{
Organization of the Development of a Business Strategy and Interpretation of Approaches Used By the Management of Russian Manufacturing Companies: The State of the Information Component of the Strategic Process
}

\author{
Nikolay A. Dimitriadi \\ Department of General and Strategic \\ Management \\ Rostov State University of Economics, \\ RSUE \\ Rostov-on-Don, Russia \\ ndimitriadi@yandex.ru \\ Vladimir M. Dzhukha \\ Department of Innovation Management \\ and Entrepreneurship \\ Rostov State University of Economics, \\ RSUE \\ Rostov-on-Don, Russia \\ dvm58@yandex.ru
}

\author{
Ttiana Yu. Sinyuk \\ Department of Anticrisis and Corporate \\ Management \\ Rostov State University of Economics, \\ RSUE \\ Rostov-on-Don, Russia \\ t_sinyuk@mail.ru \\ Olga B. Chernenko \\ Department of State Municipal \\ Management and Economic Security \\ Rostov State University of Economics, \\ $R S U E$ \\ Rostov-on-Don, Russia \\ obch2911@yandex.ru
}

\author{
Irina $\mathrm{V}$. Mishurova \\ Department of Anticrisis and Corporate \\ Management (of Affiliation) \\ Rostov State University of Economics, \\ RSUE \\ Rostov-on-Don, Russia \\ irina.mishurova@gmail.com \\ Svetlana Yu. Sharrbatsiuk \\ the Faculty of Accounting \\ EE "Grodno State Agrarian University" \\ Grodno, Republic of Belarus \\ svet_ggau@mail.ru
}

\begin{abstract}
The article presents the results determine frequency of use leaders of modern Russian manufacturers pharmaceutical products basic approaches to organizing strategic planning (corporate planning, iteration planning, intuitive planning, chaotic planning).

An assessment is made by the top management of the studied companies of the specificity of the implemented strategic process in the companies they manage for compliance definitions of the strategy (detailed action plan, principle of behavior, position, perspective, technique (aimed at disorienting a competitor)

The results obtained demonstrated the organization of the process of developing a business strategy at a small technological level. One of the most poorly organized components is the "level of structuring of the information collected."

The responses of the respondents are dominated interpretation of the specifics designed them for business strategies as a "detailed action plan" and "prospects".

The authors attribute the results to the predominant orientation of respondents to planning current activities, as well as to the presence of significant opportunities to increase the level of understanding of management by the companies studied the specifics of strategic management.
\end{abstract}

Keywords: approaches to the organization of strategic planning, business strategy, information component

\section{INTRODUCTION}

Various aspects of strategic management aimed at achieving commercial success in a dynamically changing business environment [14] attract the attention of many specialists $[2,3,7,8,13,19,22]$; appeared there studies devoted to the analysis of the evolution of strategic management concepts [11].

A number of works have demonstrated the positive role of strategic management in increasing the level of profitability of foreign economic activity [5], the resource concept [23] is being further developed. A substantial part of the research is aimed at analyzing the strategies for collecting and analyzing information [17-18, 23-25, 26], as well as methods for processing it [3], which are being implemented in the process of development. It should be noted that experts identify several approaches to organizing the strategic planning process [20]:

- corporate planning [8], which implies full control by top management over the implementation of a carefully organized strategic process;

- iteration planning (logical incrementalism) [12], which involves the formulation by top management of the main goals (to achievement of which the strategy should be focused on) and the organization of the development process in the functional subdivisions of the strategy components, which are improved as they are presented to management and recommendations are received on their adjustment;

- intuitive planning (muddling through) [21] (unambiguously assessed by experts [20] as less effective than the two previous approaches) includes solving employees a series of small tasks received from management related to the search for ways of strategic development of the company; 
- chaotic planning (garbade can), [6, 10, 15], sometimes referred to by experts as the "wastebasket", is characterized by a very chaotic choice (guide) to solve, often unrelated problems [20].

Probably, the specificity of the definition of the concept of "strategy" plays a significant role in choosing a concept of strategic planning, from which top management comes from, forming a strategic management system in the company. In the modern scientific literature one can find the definition of anti-crisis strategy [23], the classification of crises in the corporate environment, the role of strategic management technologies in overcoming crisis situations [1], and the definition of the specifics of training strategies [16]. Of considerable interest are the definitions of the concept of "strategy" systematized by G. Mintzberg [17] (the "5p" concept), which are the basis of the strategic management concepts used in practice - a plan, principle of behavior, position, perspective, technique (aimed at disorienting a competitor).

The purpose of this study is to study the relationship between the specifics of the organization of the strategic process and the interpretation of the concept of "strategy" by top management of modern Russian manufacturing companies.

\section{RESEARCH METHODS}

To achieve this goal, expert interviews (EI) and questionnaire survey were conducted.

The purpose of EI is to identify the main specific characteristics of the above approaches to the organization of strategic planning. 14 experts in the field of strategic planning took part in the EI: 9 men and 5 women, whose age ranged from 29 to 47 years, work experience in the studied area from 3,5 to 18 years.

The goals of the questionnairesare to determine the frequency of use in the studied companies of the approaches to strategic planning organization identified during the EI, as well as the level of compliance of the specifics of the strategic process in each studied company with each of the definitions of the strategy included in the questionnaire (detailed action plan, principle of behavior, position, perspective, reception (aimed at disorienting a competitor)). 43 pharmaceutical manufacturing companies were studied, 43 top managers (one from each company studied) were involved in the questionnaires: 26 men and 17 women with seniority in senior positions from 3 to 17.5 years, age - from 30 to 49 years.

Respondents were asked, using the scale presented in Table I, to assess the frequency of application in their companies when developing a business strategy of the specific characteristics of various approaches identified during the EI process, and also, using Table II, to assess the degree conformity implemented in the company of the strategic process each of the strategy definitions included in the questionnaire.
TABLE I. A SCALE FOR ASSESSING THE FREQUENCY OF APPLICATION OF SPECIFIC FEATURES OF APPROACHES TO THE ORGANIZATION OF STRATEGIC PLANNING

\begin{tabular}{|l|l|l|l|l|l|}
\hline $\begin{array}{c}\text { Quality } \\
\text { assessment }\end{array}$ & $\begin{array}{c}\text { Very } \\
\text { rarely or } \\
\text { never }\end{array}$ & Rarely & $\begin{array}{c}\text { Moder } \\
\text { ately }\end{array}$ & Often & $\begin{array}{c}\text { Almos } \\
\text { t } \\
\text { always }\end{array}$ \\
\hline $\begin{array}{c}\text { Quantitative } \\
\text { evaluation }\end{array}$ & 0 & 1 & 2 & 3 & 4 \\
\hline \multicolumn{1}{|c|}{ a. Compiled by the authors } \\
\hline
\end{tabular}

TABLE II. A SCALE FOR ASSESSING THE DEGREE OF CONFORMITY OF THE FOUNDATIONS OF THE STRATEGIC PROCESS IMPLEMENTED BY THE COMPANY WITH EACH OF THE STRATEGY DEFINITIONS INCLUDED IN THE QUESTIONNAIRE

\begin{tabular}{|l|l|l|l|l|l|}
\hline $\begin{array}{c}\text { Quality } \\
\text { assessment }\end{array}$ & $\begin{array}{c}\text { Does } \\
\text { not } \\
\text { match }\end{array}$ & $\begin{array}{c}\text { To a } \\
\text { minimu } \\
\text { m degree }\end{array}$ & $\begin{array}{c}\text { Free } \\
\text { degr } \\
\text { ee }\end{array}$ & $\begin{array}{c}\text { To a } \\
\text { signifi } \\
\text { cant } \\
\text { degree }\end{array}$ & $\begin{array}{c}\text { Compl } \\
\text { etely }\end{array}$ \\
\hline $\begin{array}{l}\text { Quantitative } \\
\text { evaluation }\end{array}$ & 0 & 1 & 2 & 3 & 4 \\
\hline \multicolumn{5}{|c|}{ a. } & \multicolumn{3}{c|}{ Compiled by the authors } \\
\hline
\end{tabular}

All experts and respondents were invited to participate in surveys based on personal contacts of the authors. Questionnaire results were processed using spreadsheet tools. For processing, we used the methodology for calculating relative weighting coefficients and ranking their values in descending order of the frequency of using individual forms of implementation of the stages of developing a business strategy, the frequency of applying specific characteristics of approaches to organizing strategic planning, and the degree to which the fundamentals of the strategic process implemented in the company are consistent with each of the form definition of strategy.

\section{RESEARCH RESULTS}

The experts who took part in EI identified four main components by which one can evaluate the role of each of the above approaches to organizing strategic planning in the implementation of the business strategy development process. The main specific characteristics of the main approaches to organizing strategic planning obtained in the process of analyzing the results of EI are presented in table III. The bottom line of table III gives an assessment of the levels of rationality and effectiveness of a business strategy developed using each of the approaches to organizing strategic planning.

The ranks of the frequency of use in the studied companies of the components of various approaches to organizing strategic planning, obtained as a result of processing the data of the questionnaire survey, are shown in Table IV. All elements of the components of the considered approaches in Table IV are designated Kij, where $\mathrm{i}$ is the number of the approach component, varies from 1 to $4, \mathrm{j}$ corresponds to the approach number (varies from 1 to 4 ): 1 "Corporate Planning" approach, 2 - "Iterative planning", 3 "Intuitive planning", 4 - "Chaotic planning". The bottom four lines (K4) show the qualitative assessments of the component "Rationality / Potential Efficiency of the Developed Business Strategy" component of the approaches under consideration that are characteristic of each of the approaches considered. 
A diagram reflecting a graphical interpretation of the results obtained during the $\mathrm{AO}$ study of the dominant approaches to strategic planning in companies is presented in "Fig. 1".

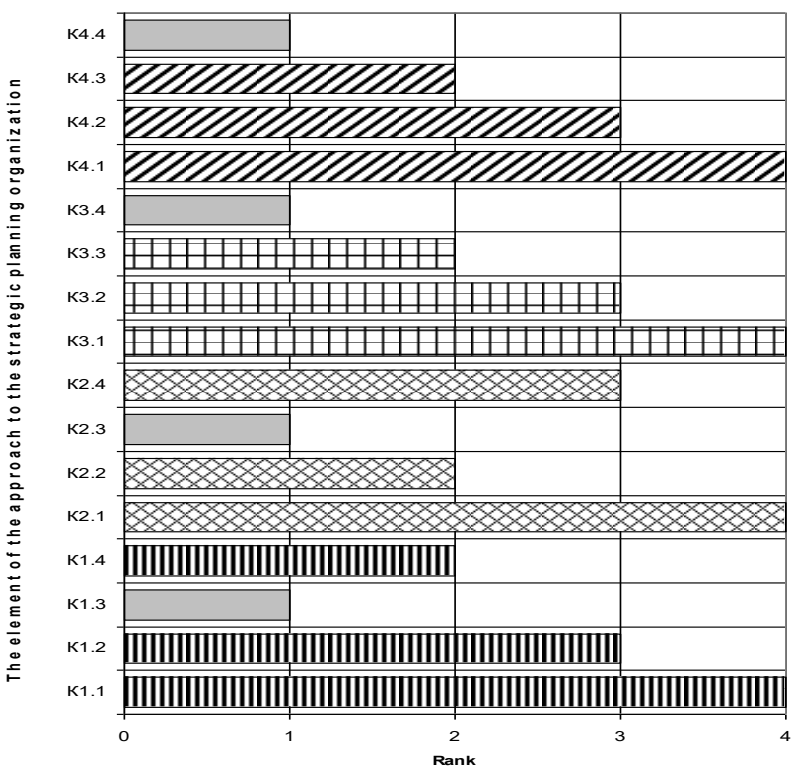

Fig. 1. Ranks of elements of approaches to the organization of strategic planning used by managers of the studied companies. (Compiled by the authors)

An analysis of the graphical interpretation of the results obtained (the components of the most commonly used approaches are highlighted in gray on the diagram) demonstrate that the companies studied:

1) implementation of the components "K1. Stages of the strategic planning process "and" K2. The role of company management "is carried out using the" Intuitive planning "approach, which describes only the general course of the strategic process, which is implemented gradually, in" small steps ", as well as formulates global goals and procedures for adapting to the actual course of the planning process;

2) implementation of the component "K3. The level of structuring of the collected information "is carried out using the" Chaotic Planning "approach, which is characterized by the predominant use of information obtained on the basis of intuition and past experience in solving emerging problems;

3) the levels of rationality / potential effectiveness of the developed business strategy (component "K4. The level of rationality / potential effectiveness of the developed business strategy") have the lowest rating.

Thus, when organizing strategic planning in the studied companies, many managers organize the process of developing a business strategy at low and low technological levels, using intuitive and chaotic approaches to organizing strategic planning. The most vulnerable component from the point of view of organizing the development process is the component "Level of structuring of the collected information".

Of significant interest are the results of questionnaires that characterize the interpretation of the correspondence between the foundations of the strategic process implemented by the company and each of the definitions of 
the strategy included in the questionnaire and are presented in Table 5 and "Fig. 2".

TABLE V. THE DEGREE OF COMPLIANCE OF THE STRATEGIC PROCESS IMPLEMENTED BY THE COMPANY WITH EACH OF THE DEFINITIONS OF THE STRATEGY INCLUDED IN THE QUESTIONNAIRE

\begin{tabular}{|l|l|l|}
\hline Definitions of Strategy & $\begin{array}{c}\text { Average } \\
\text { compliance rate }\end{array}$ & $\begin{array}{c}\text { Compliance } \\
\text { level rank }\end{array}$ \\
\hline Detailed action plan & 3,44 & 1 \\
\hline Behavior's principle & 3,02 & 3 \\
\hline Position & 2,88 & 5 \\
\hline Perspective & 3,42 & 2 \\
\hline $\begin{array}{l}\text { Maneuver oriented o the } \\
\text { rival disorientation }\end{array}$ & 3,00 & 4 \\
\hline \multicolumn{2}{|c|}{ a. Compiled by the authors } \\
\hline
\end{tabular}

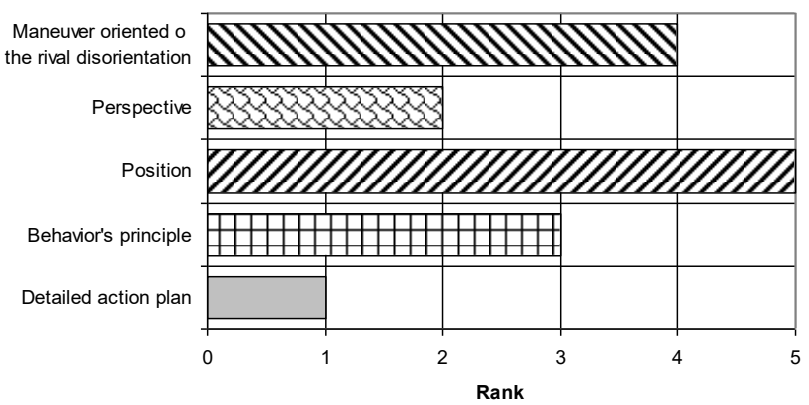

Fig. 2. Ranks of compliance of the basics of the strategic process in the studied companies with the definitions of the strategy. (Compiled by the authors)

As a result of using such an organization to create a business strategy and approaches to strategic planning, the developed business strategy is characterized by low levels of rationality and potential effectiveness; one of the main problem areas is the collection and analysis of information.

\section{CONCLUSION}

The results indicate that the responses of the respondents dominate the interpretations of the specifics of the business strategies they develop as a "detailed action plan" and "perspective". Attempts to compare these answers with the results of the first part of the questionnaires, which demonstrated the predominance of intuitive and chaotic approaches to organizing strategic planning in companies of respondents, lead to two assumptions:

- the management of the companies participating in the study is largely focused on planning current activities, while operational management does not leave time to develop more or less long-term strategies and plans;

- there are significant opportunities for increasing the understanding of the specifics of strategic management by the management of the companies studied.

To correct the situation, it is advisable to take actions aimed at bridging the noticeable "gap" between the theoretical / speculative ideas of managers about the specifics of modern approaches to strategic management and their real activities. The main areas of practical actions in this regard should be attributed to the formation of a chain of procedures that make up the structure of the strategic process, including standardization of the strategic tools, types and sources of information used at each stage.

\section{REFERENCES}

[1] G. Abatecola, "Reviewing Corporate Crises: A Strategic Management Perspective," International Journal of Business and Management, vol. 14, no. 5, 2019, pp. 21-31.

[2] F. Ackermann and C. Eden, "Strategic Management of Stakeholders: Theory and Practice," Long Range Planning, 44, 2011, pp. 179-196.

[3] A. N. Alekseev and G. V. Korolev, "Management diagnostics in strategic management," Bulletin of Science and Practice, vol. 5, no. 7, 2019, pp. 168-173. DOI: https://doi.org/10.33619/24142948/44.

[4] R. Bettis, A. Gambardella, C. E. Helfat, and W. Mitchell, "Quantitative Empirical Analysis in Strategic Management," Strategic Management Journal, 35, 2014, pp. 949-953.

[5] T. Boshkov, "Magdinceva-Shopova M. Strategic Management and Level of Company's Export Competitiveness under Economic Uncertainty," International Journal of Information, Business and Management, vol. 11, no.1, 2019, pp. 51-61.

[6] M. D. Cohen, J. G. March, and J. P. Olsen, "A Garbage Can Model of Organizational Choice," Administrative Science Quarterly, vol. 17, no. 1, March 1972, pp. 1-25.

[7] N. A. Dimitriadi, N. M. Aroyan, and T. A. Khodareva, "Sales Management Systems Effectiveness in Russian Entrepreneur Structures," Management and Business Administration, no. 4, 2013, pp. 124-136.

[8] N. A. Dimitriadi, E. A. Ivanova, M. E. Voskanov, and A. Brelik, The priority choice in the process of strategy working-out of the social economic micro region development, European Research Studies Journal, vol. 21, no. 4, 2018, pp. 45-52.

[9] B. McCaskill Donald, "Comment: Corporate Planning that Works," Management Science, 20 (4-part-ii), 1973, pp. 570-571. DOI: https://doi.org/10.1287/mnsc.20.4.570.

[10] G. Fioretti and A. Lomi, "The garbage can model of organizational choice: An agent-based reconstruction," Simulation Modelling Practice and Theory, 16, 2008, pp. 192-217.

[11] O. Furrer, H. Thomas, and A. Goussevskaia, "The structure and evolution of the strategic management field: A content analysis of 26 years of strategic management research," International Journal of Management Reviews, 10 (1), March 2008, pp. 1-23.

[12] P. Goldsmith, A. Salvador, D. Knipe, and E. Kendall, "Structural Change or Logical Incrementalism? Turbulence in the Global Meat System," For presentation at the Annual Meeting of the American Agricultural Economics Association, Long Beach, California, 28-31 July, 2002.

[13] M. M. Keupp, M. Palmié, and O. Gassmann, "The Strategic Management of Innovation: a Systematic Review and Paths for Future Research," International Journal of Management Reviews, 14 (4), pp. 367-390.

[14] T. Kimura, "The Implementation Challenge in Strategic Management: Hitachi's Transformation and Post-Transformation Experience," Journal of Strategic Management Studies, vol. 10, no. 2, March 2019, pp. 103-107.

[15] Lai Shih-Kung, "A spatial garbage-can model," Environment and Planning B: Planning and Design 2006, vol. 33, pp. 141-156.

[16] A. Meza, "Estrategias de aprendizaje. Definiciones, clasificaciones e instrumentos de medición," Propósitos y Representaciones, 1(2), 2013, pp. 193-213. DOI: http://dx.doi.org/10.20511/pyr2013. v1n2.48.

[17] H. Minzberg, S. Goshal, and G. Quinn, The Strategy Process: Concepts, Contexts, Cases, Pearson Education Limited, 2003.

[18] I. V. Mishurova, D. V. Nikolaev, N. V. Nikolaeva, T. Y. Sinyuk, and O. S. Nesterova, "Communicative technologies in crisis management of corporate structures," International Conference on Communicative Strategies of the Information Society, CSIS 2018, Advances in Social Sciences, Education, and Humanitarian Studies, vol. 289, 2019, pp. 79-83. DOI: https://doi.org/10.2991/csis18.2019.16.

[19] F. C. M. Pereira, "Evaluation of the Business Environment for use of Information in the Definition of Business Strategies," REUNA, Belo Horizonte - MG, Brasil, vol. 23, no. 3, July - September 2018, p. $32-53$. 
[24] T. Staverskaya and O. Zhyliakova, "Analysis of "Anti-Crisis Strategy" Definition Essence and its Role in Enterprise Anti-Crisis Management," Scientific Journal "ScienceRise", no. 12/1 (29), 2016, pp. 14-17.

[25] A. Sugiono, "Resource Based View in the Strategic Management Model Framework," Jurnal Pemikiran dan Penelitian Administrasi Bisnis dan Kewirausahaan, vol. 3, no. 3, December 2018, pp. 195205. DOI: https://doi.org/10.24198/adbispreneur.v3i3.19226.

[26] E. Vasile, "The Role of Information Systems in Economic Organizations for the Strategic Management," Internal Auditing and Risk Management Year XIV, no. 2 (54), June 2019, pp. 9-24. issue: Fundamental Research Issues in Strategy and Economic 1991, pp. 5-29. 